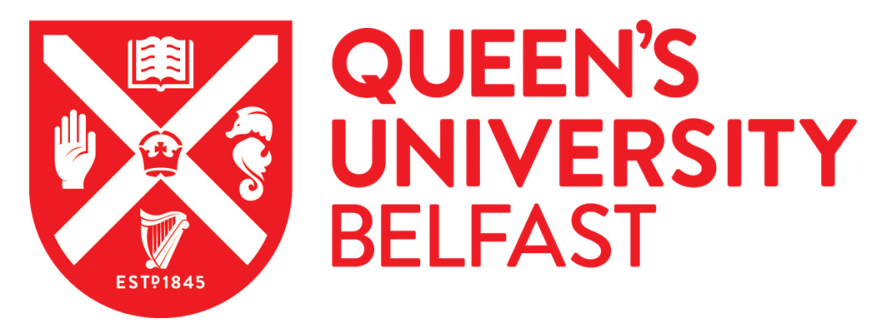

\title{
Phage Life Cycles Behind Bacterial Biodiversity
}

Olszak, T., Roszniowski, B., Latka, A., Valvano, M. A., \& Drullis-Kawa, Z. (2017). Phage Life Cycles Behind Bacterial Biodiversity. Current medicinal chemistry, 24(36), 3987-4001.

https://doi.org/10.2174/0929867324666170413100136

\section{Published in:}

Current medicinal chemistry

\section{Document Version:}

Peer reviewed version

Queen's University Belfast - Research Portal:

Link to publication record in Queen's University Belfast Research Portal

\section{Publisher rights}

(c) 2017 Bentham Science.

This work is made available online in accordance with the publisher's policies. Please refer to any applicable terms of use of the publisher.

\section{General rights}

Copyright for the publications made accessible via the Queen's University Belfast Research Portal is retained by the author(s) and / or other copyright owners and it is a condition of accessing these publications that users recognise and abide by the legal requirements associated with these rights.

Take down policy

The Research Portal is Queen's institutional repository that provides access to Queen's research output. Every effort has been made to ensure that content in the Research Portal does not infringe any person's rights, or applicable UK laws. If you discover content in the Research Portal that you believe breaches copyright or violates any law, please contact openaccess@qub.ac.uk. 


\title{
Title: Phage life cycles behind bacterial biodiversity
}

\author{
Tomasz Olszak ${ }^{1}$, Agnieszka Latka ${ }^{1}$, Bartosz Roszniowski ${ }^{1}$, Miguel A. Valvano ${ }^{2}$ and Zuzanna Drulis- \\ Kawa* ${ }^{1}$ \\ ${ }^{I}$ Department of Pathogen Biology and Immunology, Institute of Genetics and Microbiology, University \\ of Wroclaw, Przybyszewskiego 63/77, 51-148 Wroclaw, Poland \\ ${ }^{2}$ Centre for Experimental Medicine, School of Medicine, Dentistry and Biomedical Sciences, Queen's \\ University Belfast, 97 Lisburn Road, Belfast BT9 7BL, UK

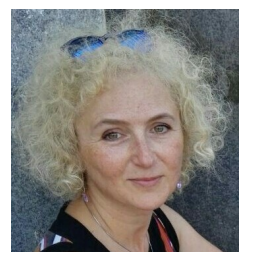

\begin{abstract}
Bacteriophages (phages or bacterial viruses) are the most abundant biological entities in our planet; their influence reaches far beyond the microorganisms they parasitize. Phages are present in every environment and shape up every bacterial population in both active and passive ways. They participate in the circulation of organic matter and drive the evolution of microorganisms by horizontal gene transfer at unprecedented scales. The mass flow of genetic information in the microbial world influences the biosphere and poses challenges for science and medicine. The genetic flow, however, depends on the fate of the viral DNA injected into the bacterial cell. The archetypal notion of phages only engaging in predator-prey relationships is slowly fading. Because of their varied development cycles, environmental conditions, and the diversity of microorganisms they parasitize, phages form a dense and highly complex web of dependencies, which has important consequences for life on Earth. The sophisticated phage-bacteria interplay includes both aggressive action (bacterial lysis) and "diplomatic negotiations (prophage domestication). Here, we review the most important mechanisms of interactions between phages and bacteria and their evolutionary consequences influencing their biodiversity.
\end{abstract}

Keywords: bacteriophages, microbial evolution, horizontal gene transfer, biodiversity

\section{INTRODUCTION}

Although discovered in the late nineteenth century, phages still are one of the greatest mysteries of modern biology. These obligate intracellular parasites of prokaryotes undeniably make the most abundant group of biological entities in the world. The total number of bacterial cells on Earth is about $10^{30}$, while the number of the phage particles is likely ten times higher [1]. Phages are commonly found in the biosphere, and the only factor limiting their occurrence is the presence of microbial hosts. Phages are almost everywhere and affect bacterial populations in all types of environments (marine, freshwater, soil, microbiome of multicellular organisms) [2].

The dynamics of the microorganism-phage interaction is perplexing; phage infections reach up to $10^{25}$ per second. Therefore, Earth functions as a giant bioreactor where bacterial and viral genetic materials are constantly undergoing random modifications driving the co-evolution of both groups [3]. Phage diversity is remarkable; for example, over 500 different phages assigned to over 30 different clusters have been isolated from just a single bacterial species like Mycobacterium smegmatis [4]. In practice, the isolation of a unique phage from the environment is possible only once. This is because phages acquire genes from the pool of phage and bacterial genomes, making the phage genomes a mosaic of exchangeable genetic modules. Recombination events cause changes in specific phage proteins or modify a large group of interdependent proteins $[3,5]$.

\footnotetext{
* Institute of Genetics and Microbiology, University of Wroclaw, Przybyszewskiego 63/77, 51-148 Wroclaw, Poland Tel./fax: +48 7132521 51, E-mail: zuzanna.drulis-kawa@uwr.edu.pl
}

Nevertheless, despite their broad genetic variability, phages have a surprisingly limited scope of lytic activity. Although phages infecting closely related bacterial species exist (e.g. within Enterobacteriaceae family) [6], the vast majority have specificity towards just one species, and some of them are specific to only a particular serotype or strain.

\section{PHAGE LIFE CYCLES}

There are four common phage life cycles: lytic, lysogenic, pseudolysogenic and chronic infection (Fig. 1). This review focuses on tailed phages, so chronic infection (typical for filamentous phages) will not be discussed and the reader can consult a recent review [7]. Each of these phage cycles involve at least five stages: adsorption, nucleic acid injection, assembly of virions, virion release, and further transmission [8].

Adsorption, one of the key steps in phage life cycles, requires the specific recognition of host surface proteins, lipopolysaccharides or other molecules (teichoic acids, fimbriae, flagella) on the bacterial cell envelope [9]. Successful recognition of bacterial surface receptors leads to permanent phage adhesion and allows penetration of the bacterial cell envelope and injection of the viral genetic material. Cell envelope penetration involves phage-encoded enzymes, such as the virion-associated peptidoglycan lysozyme, located on the phage tail, which hydrolyzes 1,4ß-linkages between $\mathrm{N}$-acetylmuramic acid and $\mathrm{N}$-acetyl-Dglucosamine residues of the cell wall peptidoglycan backbone [10]. Depending on the phage type and physiology condition of bacterial cell, the phage genome remains free standing as a plasmid-like form (episome, in pseudolysogeny; Fig. 1C \& 2E) or can be incorporated into the genome of the host (prophage, in lysogeny; Fig. 1D). 


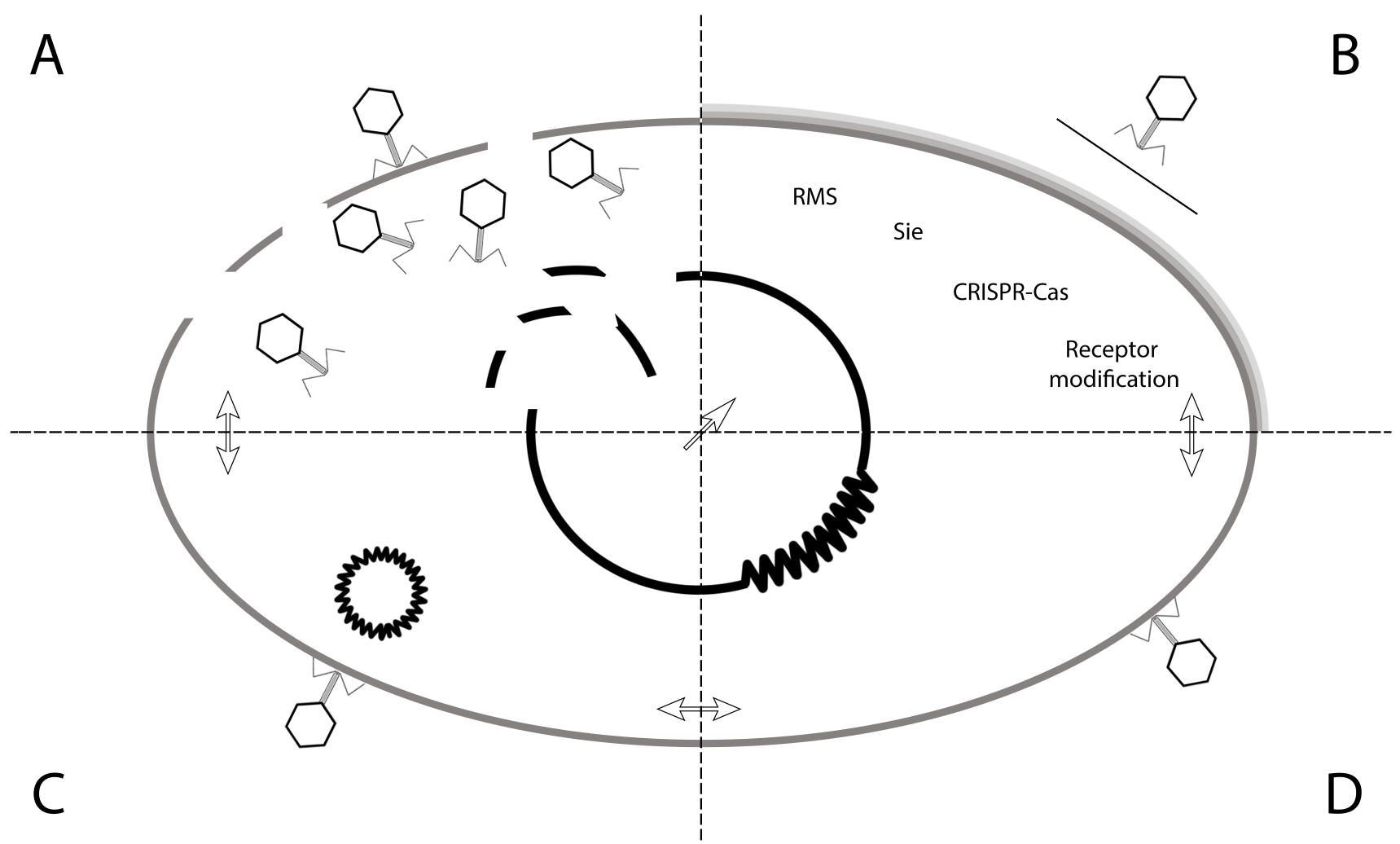

Fig. 1. Potential effects of phage infection. A - cell disruption during lytic cycle, $B$ - phage development blocked by bacterial resistance mechanisms, $\mathrm{C}$ - phage genetic material forming episome (pseudolysogeny), D - phage genetic material integrating with bacterial genome (lysogeny).

Pseudolysogeny is related to starvation stress of the bacterial host and occurs in both lytic and temperate phages. After entering the host cell, the phage genetic material remains inactive in the form of a circular episome, and the development cycle is halted until environmental conditions improve. While the development cycle of lytic phages is simply stopped, infection by temperate phages may lead to two subpopulations of bacteria - lysogens and phagecarrying cells. In other words, a bacterial population exposed to temperate phages contains both lysogens and a stable fraction of productive phage-carrying cells. Unlike lysogens, the phage genetic material in phage-carrying cells segregates asymmetrically during bacterial cell division, resulting in infected and non-infected cell lineages $[11,12]$ (Fig. 2D).

While being integrated into the host chromosome, a temperate phage can stay dormant as a prophage replicating along with the host genome. Occasionally, and mainly under stress conditions, the temperate phage proceeds to its lytic cycle (Fig. 1A). The lytic part of the phage cycle is identical for both lytic and temperate phages. Upon activation of the lytic cycle, phage infection induces the reprogramming of host genetic functions resulting in rapid replication of the viral genome and expression of structural and functional phage proteins. In subsequent steps, phage virion particles are assembled, loaded with the viral nucleic acid and released to extracellular environment upon lysis of the host cell. Bacterial membrane and cell wall disruption depends on specific lysis proteins such as endolysins (cell wall peptidoglycan hydrolases), holins (plasma membrane disruption), and spanins (destabilization of the Gramnegative bacterial outer membrane) [13-16].

Recent reports of the Sorek research group [17] show that the initiation of lytic or lysogenic cycles in temperate phages depends on specific phage-encoded signal peptides. This unique discovery demonstrates the existence of a molecular communication system between phages (reminiscent of bacterial quorum sensing). Studies on the Bacillus subtilis phage phi3T showed that in the early phase of infection (soon after viral DNA introduction) one of the first expressed phage genes are $\operatorname{aim} P, \operatorname{aim} R$, and $\operatorname{aim} X$. The AimP protein is enzymatically trimmed to a 6-residue peptide (termed arbitrium) and exported outside the bacterial cell. Arbitrium uptake by the neighboring cells occurs via bacterial oligopeptide permease transporter (OPP). The main function of arbitrium is inhibition of the intracellular phage protein AimR, which activates the transcription of the $\operatorname{aim} X$ gene (associated with the implementation of the lytic cycle). Consequently, in the initial phase of infection (at low arbitrium concentrations) phages propagate intensively by the lytic cycle. With an increasing number of infected bacterial cells arbitrium concentration increases, leading to a development cycle switch from lytic to lysogenic [17]. 


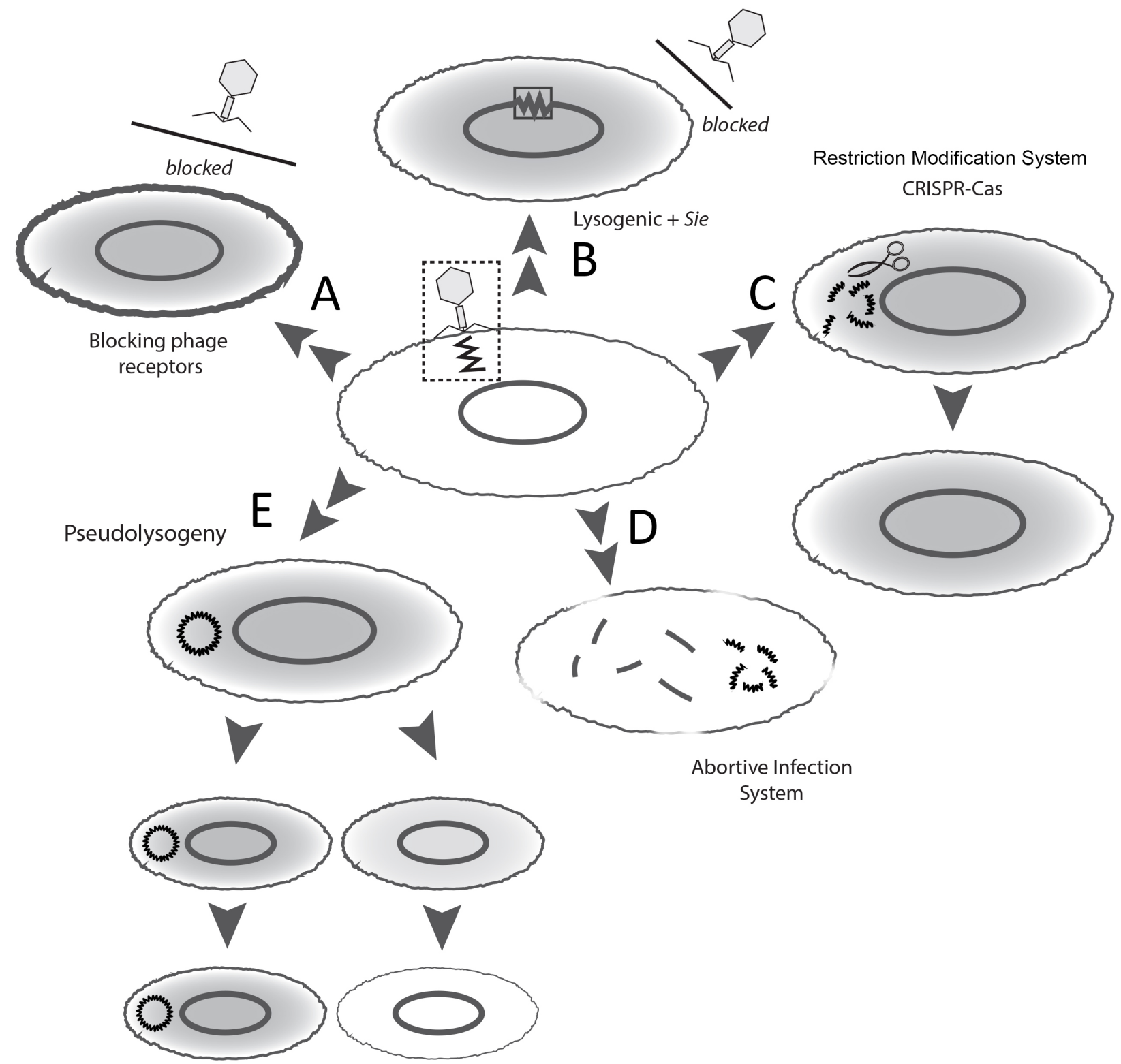

Fig. 2. Phage resistance mechanisms. A - phage receptor blocking, B - superinfection exclusion (Sie), C-phage genetic material cleavage (restriction-modification and CRISPR-Cas systems), D - abortive infection system (Abi), E - phage genetic material loss during asymmetrical cell division (pseudolysogeny).

\section{PHAGES AS DRIVERS OF MICROBIAL EVOLUTION}

The contribution of phages in horizontal gene transfer among bacteria is enormous. Transduction, the phagemediated transfer of foreign DNA (phage or bacterial) into bacterial cells, can occur as a generalized or specialized event. In generalized transduction, random fragments of the bacterial DNA are included into phage virions instead of viral DNA. These pseudoviral particles can still adsorb to cells and eject the packaged DNA into the new host. Depending on the type of donor DNA (plasmid or chromosomal), the transduced molecule can be either integrated into the chromosome of the new host by recombination or remain free in the cytoplasm replicating as a plasmid. Generalized transduction may occur during lytic step of both lytic and lysogenic life cycles [18]. In contrast, specialized transduction is typical of temperate phages and involves the prophage DNA excision from a specific integration site along with an adjacent part of the host genome. After packing into virions and infection of a new host cell, site-specific recombination (mediated by phage integrases) or homologous recombination (by bacterial recombinases) result in integration of the phage DNA into the host genome, usually at specific locations [19].

The appearance of phenotypic changes as a result of the integration of prophage into the host genome is called the 
lysogenic conversion [20]. Usually, lysogenic conversion enhances bacterial fitness by increasing their pathogenicity [21]. Coexistence of phages and bacteria in the environment along with the horizontal gene transfer, allows the bacterial host for gene pool diversification, which facilitates the adaptation to new environmental conditions [22]. Thus, phage-mediated gene transfer allows bacteria to colonize novel ecological niches, which influences subsequent gene transfer with local populations deepening bacterial diversity [13].

The lysogenic cycle occurs when phage DNA integrates into bacterial genome and propagates jointly with the host DNA. Lysogenic bacteria also become immune to secondary infections by homologous phages and display increased bacterial fitness. Together, these properties influence community composition and survivability [21]. Further, prophages in bacteria infecting eukaryotic cells may provide critical functions for intracellular invasion, propagation and dissemination (Table 1). Upon lysogenic conversion, prophages spread bacterial virulence factors such as adhesins, toxins, enzymes and other proteins enabling invasion or providing resistance to host clearance mechanisms, antibiotics (Table 2) and even other phages (when the prophage genome comprises whole CRISPR array) [23]. Temperate phages also improve the pathogen's ability to form biofilms and influence biofilm dispersal [24]. Phage particles may transfer interspecific chromosomal islands and genetic information related to other phages (e.g. pyocins or specific protein secretion systems) [21].

Table 1. Bacteria pathogenic features, encoded by genes acquired via prophages integration $[18,25,26]$.

\begin{tabular}{|l|l|l|l|}
\hline $\begin{array}{l}\text { Gene } \\
\text { name }\end{array}$ & Phage* $^{*}$ & $\begin{array}{l}\text { Encoded } \\
\text { feature }\end{array}$ & Host \\
\hline stx & $933, H 19 B$ & Shiga toxin & E. coli O157:H7 \\
\hline ctxAB & CTX $\phi$ & Cholera toxin & Vibrio cholerae \\
\hline$C 1$ & Phage C1 & $\begin{array}{l}\text { Botulinum } \\
\text { neurotoxin }\end{array}$ & $\begin{array}{l}\text { Clostridium } \\
\text { botulinum }\end{array}$ \\
\hline speA & T12 & $\begin{array}{l}\text { Erythrogenic } \\
\text { toxin }\end{array}$ & $\begin{array}{l}\text { Streptococcus } \\
\text { pyogenes }\end{array}$ \\
\hline tox & $\beta$-phage & Diphtheria toxin & $\begin{array}{l}\text { Corynebacterium } \\
\text { diphtheriae }\end{array}$ \\
\hline oac & Sf6 & $\begin{array}{l}\text { O-antigen } \\
\text { acetylase }\end{array}$ & Shigella flexneri \\
\hline $\begin{array}{l}\text { entA, } \\
\text { sak }\end{array}$ & $\phi 13$ & $\begin{array}{l}\text { Enterotoxin A, } \\
\text { Staphylokinase }\end{array}$ & $\begin{array}{l}\text { Staphylococcus } \\
\text { aureus }\end{array}$ \\
\hline nanH & Gifsy-2 & Neuraminidase & $\begin{array}{l}\text { Salmonella } \\
\text { enterica }\end{array}$ \\
\hline
\end{tabular}

Two types of lysogenic conversion influencing bacterial pathogenesis can be distinguished. In one type, the expression of bacterial virulence factors takes place from the prophage during lysogeny, and in the other phageencoded virulence factors are expressed during the induction of the lytic cycle mode [24,30]. Negative lysogenic conversion arises when phage DNA integration occurs in crucial regions of the genome for specific functions. In this case, the phage genetic material simply disrupts the integrity of particular bacterial genes [24].
Table 2. Antibiotic resistance encoded by genes acquired via prophages integration. The table focuses mostly on $\beta$-lactamases since $\beta$-lactam antibiotics are widely used due to their clinical efficacy and low toxicity [27-29].

\begin{tabular}{|l|l|l|}
\hline $\begin{array}{l}\text { Gene } \\
\text { name }\end{array}$ & Encoded feature & Host \\
\hline mecA & $\begin{array}{l}\text { Penicillin-binding } \\
\text { protein }\end{array}$ & Staphylococcus aureus \\
\hline bla $_{T E M}$ & $\beta$-lactamase & Escherichia coli \\
\hline bla $_{P S E-1}$ & $\beta$-lactamase & Campylobacter jejuni \\
\hline bla $_{O X A-2}$ & $\beta$-lactamase & Pseudomonas aeruginosa \\
\hline bla $_{P S E}$ & $\beta$-lactamase & Salmonella enterica \\
\hline
\end{tabular}

Even if the phage genome does not encode any virulence factors, prophage can affect bacterial toxin production and secretion by gene expression regulation. This kind of phage regulatory switch is also called active lysogeny [30]. Gene disruption may lead to gene inactivation and therefore creation of new phenotypes (e.g. lipase and $\beta$-toxin negative Staphylococcus aureus phenotype caused by integration of two relatively small prophages into genome - L54a and phi13) [31].

\section{PROPHAGE DOMESTICATION BY THE HOST CELL}

The viral genetic material can be modified inside bacterial host, which may lead to damage by nucleotide non-synonymous substitution or deletion of genes essential for the phage developmental cycle. This process may depend on random mutations or poorly understood bacterial mechanisms leading to a gradual degradation of the viral genome retaining only beneficial genes for the bacterium. Domesticated prophages are subjected to further changes resulting from spontaneous mutations or recombination with other (also unrelated) phages, plasmids and host DNA [32,33].

Phage genetic material in the form of prophages may comprise up to $20 \%$ of the bacterial genome. The presence of several phage-like sequences within the genome of almost every bacterial species underscores the generality of this phenomenon. Most of these prophages are no longer inducible and therefore referred to as "cryptic" prophages). Non-inducible prophages may be present in the host cell in four forms depending on the degree of genome degradation associated with the integration of viral and bacterial genetic material: defective prophages, satellite phages, bacteriocins and other prophage-related entities such as "gene transfer agents". Simplifying the viral genome is a continuous process, but the selection mechanism works differently in particular bacterial species and also depends on environmental conditions. Therefore, some bacterial species retain a large part of the phage genome, while only the residual genes (e.g. bacteriocins) are preserved in others. Conceptually, the process of assimilation of prophage DNA by the host genome can be divided into several stages. The first stage of results in a defective prophage unable to perform the lytic cycle usually due to loss of functions (by 
mutation or gene deletion) required for DNA packaging into the phage capsid [34]. The next stage results in a "satellite" phage (e.g. Escherichia coli phage P4) lacking the genes encoding the capsid structural proteins and requiring a specific helper phage to propagate [35]. Additional stages involve the progressive reduction of the phage genome to only residual genes encoding specific proteins (e.g. phagetail-like bacteriocins) [34] or the formation of gene transfer agents. These are phage-like particles that transfer random elements of the bacterial genome to other bacteria. In this case, the mechanism of gene transfer resembles generalized transduction but in contrast to the phages, gene transfer agents do not carry the genes encoding the phage structure. Moreover, because of the small capacity of the head, these particles are unable to carry large amount of DNA necessary to generate functional phage-like particles [36].

\section{BACTERIA AND PHAGE INTERPLAY - COADAPTATION}

The interplay between bacteria and phages leads to coadaptation. Thus, phage genes contribute to bacterial fitness under certain environmental pressures, and also the presence of the phage alters how bacteria interact with other phages. Indeed, not only the bacterial genome is the subject of phage-induced changes, but also the pattern of bacterial gene expression can be modified by phages to preclude superinfection by other phages. This can even include situations where two distinct integrated phages can lead to co-resistance [37]. The Red Queen hypothesis, introduced by Leigh Van Valen in 1973, assumes that species must constantly evolve and adapt not only to better reproduce, but also to effectively compete with other organisms in the ever-changing environment. This concept explains the two phenomena: co-evolution of competing species driving the extinction of slower-adapting ones and advantage of sexual reproduction over the asexual one (in case of the diploid organisms). The adaptive changes of one species within a particular niche usually causes selection pressure on other species what resembles an endless arms race [38]. The Red Queen hypothesis works in the relations of competition, predator prey and parasite-host as well. According to the Red Queen hypothesis, competition between phage and bacteria (predator and prey) leads to an endless "arm race" [39], since constant modification and selection of new features takes place leading to bacterial response to phage appearance and then rapid reaction of phage to resistance mechanism developed by the prey $[40,41]$. The classic lytic cycle leading to the lysis of almost the entire population of a particular bacterial species exemplifies the predator-prey relationship and co-evolution of phage and its host. The lytic cycle is the classical example of predator-prey relationship, where phages exploit particular bacterial population to propagate more effectively. In this case, phage predation results in the lysis of the vast majority of susceptible bacterial cells within the population [40]. However, the complete eradication of the microorganisms never occurs, because persisters (dormant, highly tolerant to antimicrobials variants of regular cells) arise in every bacterial community [42] as well as phage-resistant clones induced under the selective pressure caused by phage invasion. Thus, two types of cells are responsible for the microbial community revival. Bacterial resistance to phages may be established through several possible mechanisms. Phage infection induces the activation of bacterial defense systems, such as restriction-modification, the CRISPR-Cas, and abortive infection, or leads to the survival of variants possessing modified phage receptor. No matter which of the abovementioned mechanisms occur, the emergence of phage-resistant clones causes a selective pressure on the phage [40].

Phage infection induces activation of bacterial defense systems, such as restriction-modification, the CRISPR-Cas (see below, paragraph 6.), and abortive infection [40]. CRISPR-Cas provides adaptive immunity to phages or plasmids, allowing bacteria to recognize and degrade foreign DNA entering the cell [43]. Conversely, phages develop mechanisms preventing abortive infection (e.g. through the production of bacterial-like antitoxins), disarm the CRISPR-Cas system (e.g. by mutations in protospaceradjacent motifs or preventing formation of the CRISPR-Cas complexes), and inactivate restriction-modification systems (e.g. by methylation of phage DNA or reduction in the frequency of restriction sites by mutation) [41]. The situation becomes more complicated when the lytic phage infects a bacterium in unfavorable environmental conditions becoming pseudolysogenic (Fig. 2E). In this case, the host remains viable until the environmental conditions become more favorable for bacterial growth, thus providing a larger number of host bacterial cells for phage multiplication [11]. Pseudolysogeny was observed for the first time by Frederick Twort in 1915 [44], but for many years, researchers were unable to clearly define this phenomenon. Ripp \& Miller described pseudolysogeny as an unstable state in the phage development cycle where the viral genetic material remains dormant (so called preprophage) despite injection into a sensitive host cell. There is neither integration into the genome nor lytic cycle initiation [45]. The direct cause of this halt in the phage development cycle remains unknown. However, pseudolysogeny typically is related to the starvation stress of the host, when the bacterium cannot replicate the phage genetic material or produce phage proteins efficiently. This state is a kind of adaptation of the phage, enabling to survive in the nutrient-deficient environment. Despite the preprophage cannot replicate the half-life of the phage particle increases significantly because it can be passed to host daughter cells. The preprophage resumes the regular development cycle once the nutrient conditions become permissive for the growth of the host population [30,46]. Generally, bacteria evolve by expanding their resistance while phages adapt by broadening the host range [47]. The relation between bacteria and phages is by definition antagonistic so their co-evolution is rather a reciprocal process. The selection pressure associated with the phage predation leads to the acquisition of new mechanisms of resistance. Conversely, the phages evolve towards extending the host range to capture emerging phageresistant clones. Some phages possess more than one type of tail fibers/spikes recognizing host receptor. E. coli phages K1-5, and Salmonella phage SP6 produce two tail protein with endosialidase and lyase activity enabling the infection of different host serotypes [48]. Phage phi92 and PVP-SE1 from myoviruses have five/six different receptor binding 
proteins being tail spikes or tail fibers $[49,50]$. The existence of phages possessing more than one sets of enzymatically active tail spikes, specific to different host receptors is an example of broadening the host range by acquisition of new enzymes using horizontal gene transfer. The interactions between phages and their hosts are not limited to recognition and adhesion. In fact, phage development cycle is adapted to the host biology at every single stage. The end result is that bacteria cannot develop resistance to all phages and phages cannot attack all bacteria cells [47]. This brings a trade-off, which is associated with the phenomenon of antagonistic pleiotropy and limited genetic capacity (too many genes is a considerable energy expenditure) [51].

Bacterial DNA sequences responsible for phage resistance are highly changeable, and some of them may even develop different cellular functions. This process is called "exaptation" (shift of function), which refers to two ecological situations: when the feature adapts to a new function by natural selection or when the origin of feature is not connected to natural selection but further is co-opted to a new function [52]. Neofunctionalization is preceded by modification of gene of interest like domain shuffling, modified regulation or duplication. The new feature appeared as a result of duplication, changing gene regulatory network, but the final step on the way of neofunctionalization is refinement of primitive feature [53]. Another example of exaptation is the change of a restriction-modification system, originally directed against foreign DNA molecules/phages, into a system participating in epigenetic modifications and regulating bacterial pathogenicity by turning on and off genes responsible for colonization, immune system avoidance or environmental adaptation [40]. That occurred by loss of REase activity with maintaining of MTase activity, which started to function as epigenetic regulator [54]. This may regulate the foreign DNA uptake and "bacterial suicide" by autolytic DNA degradation [40]. It can also methylate bacterial genome, leading to switching on and off different genes, what influence bacterial ability to adapt to new milieu, colonization and immune avoidance $[55,56]$. Other example of exaptation is a use of Toxin-Antitoxin module to cut mRNA, aborting reversible the translation event, as a response to stressing factors, like phage infection $[57,58]$. Further, lytic phages can provide selective pressure enabling the propagation of less virulent bacterial strains through modification or loss of surface structures that act as virulence factors and are also used as phage receptors [59].

Phages can mutate in bacterial monoculture, while higher diversity arising from independently acquired fragments of phage DNA (e.g. via the CRISPR-Cas system) makes phage adaptation more difficult [60]. CRISPR-Cas immune bacteria readily dominate among CRISPR-Cas deficient ones, since high variety of acquired phage DNA fragments makes phage adaptation (by point mutation) less likely [60]. Similarly, inhibition of coevolution occurs in phage tail fiber - bacterial receptor coadaptation. Bacteria can introduce unrestricted changes in the receptor while phage must adapt to a specific one [47]. However, every structural change of bacterial receptor is a trade-off; bacteria gain phage resistance, but often lose a virulence factor [47]. Since hypervariable genomic regions encode phage receptors, receptor alternation becomes even more frequent by the acquisition of new genes from a foreign pool [61]. The structures used by phages as adhesion receptors may be crucial for bacterial pathogenicity and physiology, meaning every permanent change in the receptor composition and structure can be undesirable for bacteria, therefore some of them use so called phase variation, where the receptor expression can be reversibly inhibited [62]. Phage adhesion receptors usually are important virulence factors or they are required for key physiological processes. Examples of these receptors are smooth type of LPS, capsule, type-IV pili, which serve for pathogen attachment, protection against immune system activity (phagocytosis, complement activity) or biofilm formation. Thus, changes in the conformation or structure of bacterial surface components can reduce bacterial virulence. Some bacteria can eliminate the risk of negative consequences of receptor structural changes by phase variation. This mechanism temporarily inhibits the expression of a phage receptor [62]. But even though, the phages develop specific strategies to oppose that kind of changes, such as reverse transcriptase-mediated tropism used by Bordetella phage $[63,64]$.

\section{PHAGE - RESISTANCE MECHANISMS}

Due to the multi-stage character of phage infection, bacteria may develop various methods of prevention of the invasion, which protect individual cells or the entire population (Fig. 2). Four main resistance mechanisms may occur: blocking the access of phages to bacterial receptors, preventing entry of phage DNA, digestion of nucleic acids and abortive infection systems. Phage adsorption is one of the most complex steps of the phage infection cycle, as phage particles must localize the proper receptor among thousands of cell envelope components. Some bacteria prevent absorption of the phages (Fig. 2A) by masking receptors with various components, removing or modifying them, or by forming an extracellular matrix. For example, different masking phage receptors strategies, such as production of masking lipoproteins (Llp) or cell-wall anchored proteins (protein A), have been described among strains of $E$. coli or $S$. aureus, respectively, which provide a physical barrier preventing phage attachment $[65,66]$. The receptor can be removed, as in Campylobacter jejuni, by inhibiting flagellin production $[67,68]$. Bacteria can also modify outer membrane structures, such as changes in the E. coli TolC and OmpA proteins [69-71]. Extracellular structures such as exopolysaccharide or lipopolysaccharide can also mask bacteria receptors [72,73]. Lipopolysaccharide is also a common receptor for the phage adhesion, and a common way to block phage infection involves changing the composition of the O-antigen lipopolysaccharide or shortening its structure [74]. The next group of resistance mechanisms involves preventing the entry of phage DNA (Fig. 2B). They are based on superinfection exclusion ( $\mathrm{Sie}$ ) proteins, which are encoded by either lytic or lysogenic phages. Sie proteins are anchored on the cell membrane or associated with other membrane components and prevent DNA from reaching cytoplasm of the host $[75,76]$. Prophages may encode more than one Sie system [77]. 
Another way to counteract phages is by cleaving the phage's DNA, typically using a restriction-modification or CRISPR-Cas systems (Fig. 2C). Both systems are directed against newly acquired foreign DNA and may work in synergy. Most bacteria have restriction-modification proteins classified into four groups (type I - IV) [78-80], which recognize and digest cytoplasmic DNA that is not methylated at appropriate sites. In some cases, the acquired phage DNA is already modified by phage methylases and protected from the restriction event.

The CRISPR-Cas system, mentioned before, consists of three main parts: regions of clustered, palindromic repeats, spacers and Cas proteins. The system comprises two classes, which incorporates five types. Types II and V belong to CRISPR-Cas class 2, while types I, III and IV are fitted to CRISPR class 1 [81]. Regardless of class the operation mode can be divided into adaptation to new nucleic acid, expression and interference. Adaptation begins with the recognition of invading DNA, prior fragmented with synergistic R-M system [82]. The fragment of the DNA is afterwards equipped with leader-end repeats and integrated into the system by endonuclease-acting Cas 1 and Cas 2 . During the expression phase, the palindromic repeats region as well cas genes are transcribed to the pre-CRISPRs or precRNAs, which are template for crRNA possessing newly acquired invading DNA fragment. This process differs between classes of CRISPR-Cas systems, nonetheless it leads to creation of protein and ribonucleoprotein complexes, which can recognize hostile DNA. When the expression is complete, the complexes locate and degrade the invading DNA [83]. CRISPR-Cas system has been identified in almost $40 \%$ of bacteria and $90 \%$ of Archaea representatives $[84,85]$.

Another method of defense against phages is abortive infection (Fig. 2D), which involves stopping phage multiplication by inducing death of the infected bacterial cell death. The elimination of a low quantity of single cells enables the larger bacterial population to survive, since progeny virions are incomplete and cannot be released into the environment. Abortive infection systems may work at different stages of the phage lifecycle (replication, transcription, translation, or DNA packing) [71,86-88].

The best studied abortive infection systems for Gramnegative bacteria are described in E. coli. The twocomponent RexAB system causes the membrane potential disruption as the consequence of activation by protein-DNA complex formed during phage DNA injection. The second, working on the translation level, is the Lit system cleaving the elongation factor EF-Tu what leads to the inhibition of protein synthesis. Another is the anticodon nuclease Prr system or PifA based on membrane protein. An important mechanism of abortive infection systems involves toxinantitoxins controlling bacterial the cell death via proteinprotein, protein-RNA or RNA-RNA interactions (MazEF and hok-sok in E. coli). The most detailed abortive infection systems studied in Gram-positive occur in lactic bacteria, which have more than twenty different mechanisms (abortive infection systems A-Z) recognizing and stopping phage infection at various steps of the life cycle. [71,8688].

\section{PHAGES AS GLOBAL ECOSYSTEM REGULATORS}

Due to their abundance and diversity, phages have a major influence on local and global ecosystems. By controlling the size of bacterial populations or communities, phages contribute to the redistribution of nutrients in the environment. In the marine environment alone, phage lytic activity releases about $10^{8}$ tons of organic carbon daily [89]. Phages in the marine ecosystem are associated with the phenomenon of "microbial loop", which results in the recirculation of more than half of organic matter in the oceans. This revival of the food chain through the enrichment of the local environment in organic components available for microorganisms also transmit nutrients up to the food chain or alternatively, store them in the form of sea bottom sediments [20,90]. Apart from obvious effects on the carbon cycle, phages also participate in the redistribution of nitrogen and phosphorus, which directly affects the growth of phytoplankton [91,92]. The microbial loop operates not only on a global scale. Phages also affect the circulation of matter locally, such in the process of bioremediation of mine water or in the development of the intestinal flora $[93,94]$.

\section{BIOLOGICAL INTERACTIONS BETWEEN PHAGES AND MICROORGANISMS}

The influence of phages on the environment extends beyond the regulation of microbial populations and the circulation of matter in nature. Sophisticated interactions between phages and their hosts go far beyond the typical predatorprey relationships (Fig. 3). Indeed, lysogeny shapes an ecosystem's metagenomics and influences the evolution of both microorganisms and phages. Temperate phages are involved in horizontal gene transfer, which often contributes to beneficial changes in the metabolism of the host. Lysogenic conversion under appropriate conditions results in the acquisition of novel virulence factors (e.g. exotoxins or the ability of biofilm formation), resistance mechanisms (e.g. for antibiotics or phages), and upregulation of the metabolism in general. All these benefits have a dynamic impact on the local environment by giving an advantage over other microorganisms and remodeling ecological niches [95]. The interactions between phages and microorganisms do not fall within the classical paradigm of parasitism. Indeed, depending on the type of the replication cycle, these relationships can be mutualistic or antagonistic, such as predator-prey, parasitehost and allelopathy (production of the substances that can have positive or negative influence on other organisms) $[13,96]$. In specific niches, phages condition bacterial abundance. Various phage-bacteria interactions can be distinguished. Although neutralism - lack of interactions between bacteria and phage (Fig. 3A), should be theoretically the most common state, it is difficult to prove since many of the other interactions can influence bacteria and phages indirectly. For example, "neutral" bacteria may benefit from the release of biomass after a lysis event, in which case this indirect interaction could be considered as commensalism (Fig. 3B). 
A
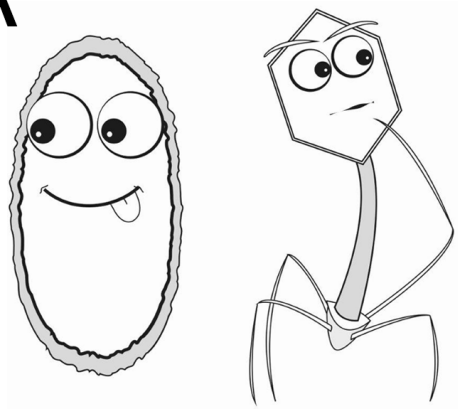

C

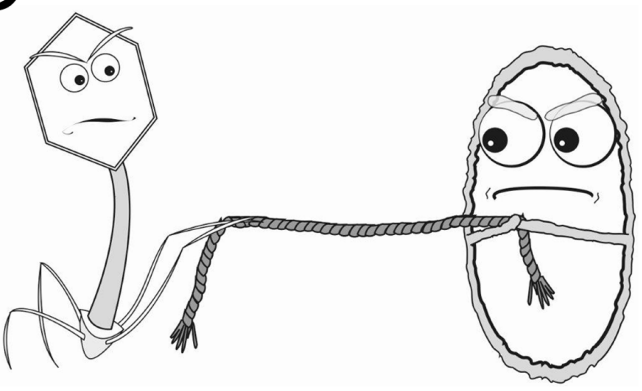

E
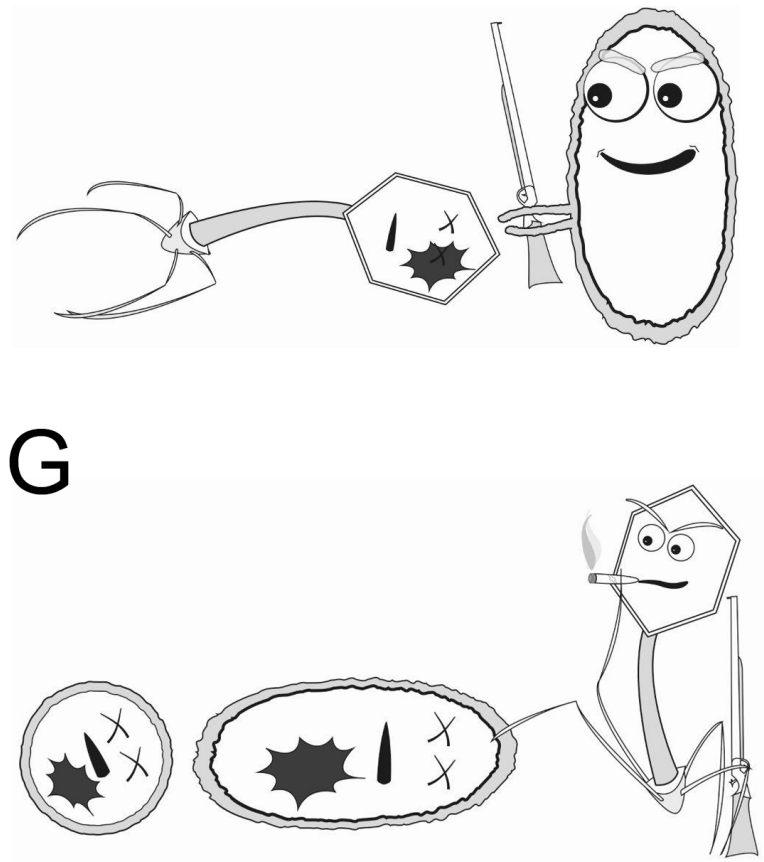

B

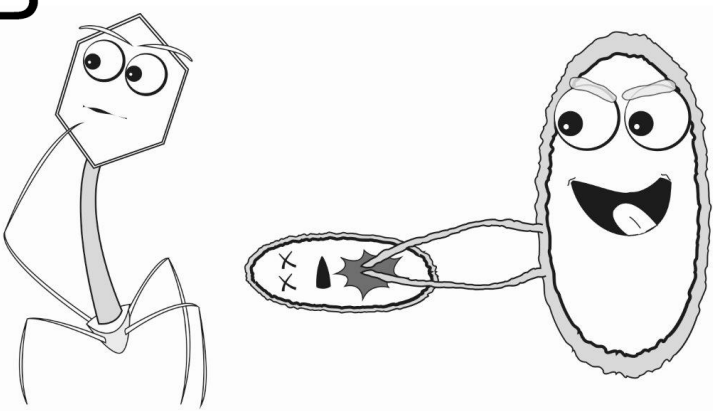

D

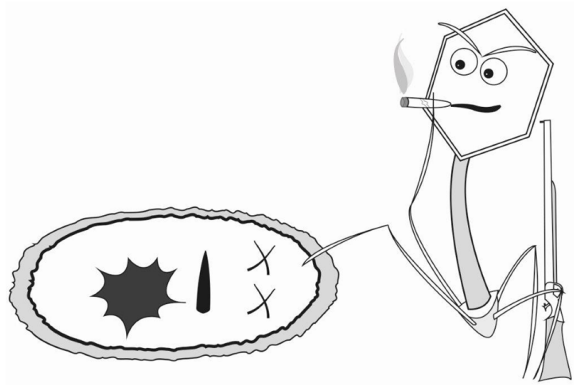

F

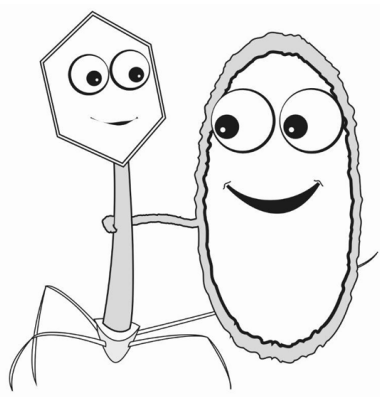

$\mathrm{H}$

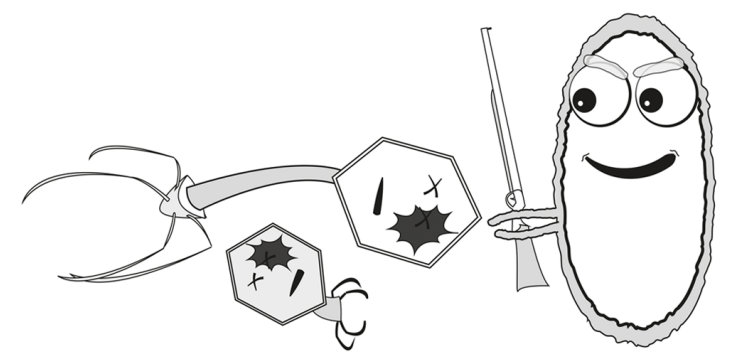

Fig. 3. Interactions between phages and bacteria. A - neutralism; B - commensalism, C - competition; D, E-predator-prey; F-mutualism; $\mathrm{G}, \mathrm{H}$ - amensalism.

The most common interaction between phages and bacteria is competition (Fig. 3C). Phages compete for the host with other predators such as predatory bacteria (e.g. Bdellovibrio) or other phages [13]. Competition is connected to another antagonistic interaction - predatorprey, which can be observed for both phage and bacteria (Fig. 3D). Predation is one of the ways for phages to control dominant bacterial populations, diversifying prokaryotes by allowing the non-dominants to co-exist $[97,98]$. Conversely, the predator-prey interaction may be adverse for phages (Fig. 3E) leaving them as a prey to the bacteria, which may use them as nutrient source [13]. Another type of interaction between phage and bacteria is mutualism (Fig. 3F), such as lysogenic conversion, which often increases the fitness of 
the host and protects the prophage from unfavorable environmental conditions $[99,100]$.

Amensalism implies an adverse effect on phages while the effect on bacteria is neutral, or vice versa (Fig. $3 \mathrm{G}$ ). The example of negative interaction for phage and neutral for bacteria (Fig. 3H) can be the destruction of the nonantagonistic phage by the ecto-enzymes secreted by bacteria [13].

Lysogenic cycle, typical of temperate phages, can be considered in three ways. First, the genetic material of the phage is replicated and continuously propagated by the bacteria. Second, the integrated prophage often provides new virulence and resistance mechanisms that enhance the lysogen's competitive advantage and protect it from secondary phage infection (superinfection exclusion). This type of relationship can be described as mutualism [95]. Third, temperate phages can become allelopathic factors if the progeny phages are released in a heterogeneous bacterial community (infected and uninfected by phage). Population of lysogens in this case, wins the competition with noninfected strains by limiting their proliferation [101,102]. Thus, for genetically identical strains differing only in the presence of the prophage, this particular phage can be simultaneously allelopathic (for non-infected cells), and mutualistic (for cells carrying a prophage) [103].

\section{PHAGE - BACTERIUM - ENVIRONMENTAL INTERPLAY}

Phage ecology should be investigated as a three-sided interplay since the surrounding environment also influences phage-host interactions [23]. Even if the phage can kill most of the bacterial population in vitro, multiple factors (e.g. some chemical compounds, immune system, digestive enzymes or even transfer by circulatory system) can inhibit phage predation in vivo. Bacterial starvation can be seen as phage pseudolysogeny inducing factor, since this kind of phage lifecycle may support phage survival [45]. Traditional predator-prey interaction patterns can be found between bacteria and phages co-existing in simple systems where the phage mode of action is mainly lytic. Phages specific for saprophytic bacteria frequently carry out a lysogenic cycle $(60-70 \%$ of gut bacteria are lysogenic) $[23,24]$.

Abiotic factors (e.g. nutrient concentration) in environments occupied by particular phages and bacteria affect the generation of progeny phages better suited to the bacteria living in the same niche [104]. Similarly, the adaptation to higher temperature makes bacteria more resistant to phages, while phages become more infectious [105]. Propagation of animal and human pathogens at $37^{\circ}$ $\mathrm{C}$ increases their motility, what helps to colonize new niches, but alters virulence factors expression. On the other hand, under these conditions there is a cost for phages in terms of developing phage resistance (Fig. 2). Further, motile bacterial clones (generated as a result of temperature selection) encounter phages more frequently, leading to faster co-evolution of bacteria and their predators [106]. In variable environments (with frequent and severe conditions fluctuations) and in nutritionally poor environments the temperate phages are generally more successful than lytic or dormant ones [107].

\section{BIOFILM COMPLICATES PHAGE - BACTERIA INTERACTIONS}

Interactions between phages and microorganisms are much simpler to model in the context of free-living bacteria. However, this situation is rare in nature since bacterial populations usually reside in multicellular biofilms. Biofilms have a dense extracellular matrix containing exopolysaccharides, extracellular DNA, proteins, amyloid fibers, fatty acids, phages and, of course, bacterial cells of varied phenotypes and metabolic activities [108]. The structure of biofilms constantly evolves under the influence of environmental factors including phages. Temperate phages are actively involved in both the creation and dispersion of biofilms. For example, strains of Pseudomonas aeruginosa lacking of Pf4 prophage form less stable biofilm communities than wild type. Biofilm dispersion and release of the bacterial cells involved in new niche colonization are also limited in this case, since the absence of prophage prevents the degradation of the surface layers of the biofilm $[109,110]$. The thick biofilm matrix forms a physical barrier against external lytic phage invasion and antimicrobials. Unlike antibiotics, some phages are equipped with enzymes such as exopolysaccharide depolymerases enabling virions to penetrate into the biofilm matrix [111]. However, the phages have established such mechanisms during coevolution for successful infection, and for the release of progeny from biofilm structure. Therefore, the local damage of the biofilm structure may not provide an enormous improvement in therapy when applied as supportive for standard antibiotics. Moreover, the possible bacteria-phage interaction scenarios become more complicated in the case of biofilm-forming bacteria due to the large phenotypic variation of microcolonies within biofilms [112].

\section{PHAGE ABUNDANCE VERSUS BACTERIAL ABUNDANCE}

According to Odum (1953), the complexity of the environment correlates with its productivity. However, different components of a particular environment are correlated with its productivity in different ways. More specifically, the diversity of bacteria is inversely proportional to the productivity of the environment and the diversity of phages [113]. Two models of bacterial population dynamics in natural environments can be considered [114]. A constant-diversity dynamics model, which dominates in environments where free-living cells co-exist and compete while constantly being exposed to phage predation, and a periodic-selection model more suitable for environments where phage pressure is limited (e.g. biofilms, host intracellular environment).

In the environments of limited nutrient availability, with no phage pressure, the susceptible strains can simply eliminate the phage-resistant ones because of fast rate of propagation. If phage predation occurs, both types of bacteria (phage-sensitive and phage-resistant) can co-exist, 
depending on resistance costs and the actual state of environment [115]. Phage predation does not lead to bacterial elimination, but rather to the establishment of steady state where one phage can defeat another just by using the same host. More aggressive phages win the competition because of higher burst size, better adhesion rates or shorter latent periods. This competition underscores that the diversity of bacteria is always higher than the diversity of phages, which gives bacteria an edge in the "arms race" [116]

Under favorable conditions, the higher growth rate is beneficial for both bacteria and lytic phages [116]. According to "killing the winner" hypothesis, the dominance of susceptible bacteria population in limited niches implies accessibility of high numbers of the host cells for rapid phage propagation. As a result, the niche becomes colonized by other (phage-resistant) strains or species because of dominant population decimation [117]. Obviously, this is detrimental to the strain, which loses dominance. However, the lytic phage action against competitive strains is advantageous to the phage-resistant bacteria and switches the relation status from host-parasite to mutual companions [22]. The case of single lytic phage pressure described above is of course uncommon. In fact, in every niche there are various phages what increase the probability of cross-infections leading to considerable genetic and phenotypic diversity of bacterial strains [21]. This matter is far more complex due to the existence of the temperate phages, which may convert seemingly homogenous bacterial population into mixture of phenotypically different clones. Moreover, a superinfection exclusion ( $\mathrm{Sie}$ ) mechanism protects the bacterial host from secondary infection by closely related phages, being another factor driving phage evolution. Differences in phageresistance, induced by temperate phages, lead to higher diversification among virulent lytic phages [116,118,119].

Knowles et al. (2016) propose the "piggyback the winner" model in which highly dense populations suffer greater selection pressure to initiate lysogenic cycles, which maintains both high density of bacteria and the phage population. In such situation, the prophage causes bacterial resistance to superinfection, [120]. Establishing phage resistance by mutation, which typically involves loss of gene function may lead to reduced growth rate (compared to phage susceptible bacteria) or susceptibility to phagocytosis [23].

\section{CONCLUSIONS}

The importance of phages for the environment and evolution of microorganisms cannot be appreciated without realizing that all processes and interactions occurring in the world of microorganisms have molecular underpinnings. Evolution promotes specific phenotypes in specific environments, as every ecological niche has its own set of biotic and abiotic factors, influencing the phage and bacterial populations and affecting the dynamics of their interactions. Ongoing arms race between bacteria and phages led to the emergence of phage-resistance mechanisms (RM, Abi, Sie, CRISPR-Cas, receptor modifications), and at the same time enabled the spread of viral genetic material in various ways (lytic cycle, lysogeny, pseudolysogeny). The widespread phenomenon of horizontal gene transfer causes the constant mixing of phage and bacterial genomes and their almost unlimited transfer between strains and species. The natural mechanism of selection pressure, depending on environmental conditions, preserves or removes acquired genes contributing to the increased the versatility of both microorganisms and phages. Acquisition of new resistance and virulence factors by bacteria increased their pathogenicity, but the preservation of the acquired features depends mainly on the local environment. The introduction of a specific phage to the environment most often generates distinct bacterial clones with different phenotypes. Phages, by many considered as remedies against increasing antibiotic resistance, may also be Trojan horses of antibacterial therapy.

\section{CONFLICT OF INTEREST}

The authors declare that they have no competing interests.

\section{ACKNOWLEDGEMENTS}

This project was financed from the means of the National Science Centre, Poland, granted on the basis of the decision No. UMO-2015/18/M/NZ6/00413. The authors acknowledge COST (European Cooperation in the field of Scientific and Technical Research) action BM1003, "Microbial cell surface determinants of virulence as targets for new therapeutics in Cystic Fibrosis".

\section{REFERENCES}

[1] Whitman, W. B.; Coleman, D. C.; Wiebe, W. J. Prokaryotes: The Unseen Majority. Proc. Natl. Acad. Sci. U. S. A. 1998, 95 (12), 6578-6583.

[2] Srinivasiah, S.; Bhavsar, J.; Thapar, K.; Liles, M.; Schoenfeld, T.; Wommack, K. E. Phages across the Biosphere: Contrasts of Viruses in Soil and Aquatic Environments. Res. Microbiol. 2008, 159 (5), 349-357.

[3] Pedulla, M. L.; Ford, M. E.; Houtz, J. M.; Karthikeyan, T.; Wadsworth, C.; Lewis, J. A.; Jacobs-Sera, D.; Falbo, J.; Gross, J.; Pannunzio, N. R.; Brucker, W.; Kumar, V.; Kandasamy, J.; Keenan, L.; Bardarov, S.; Kriakov, J.; Lawrence, J. G.; Jacobs, W. R.; Hendrix, R. W.; Hatfull, G. F. Origins of Highly Mosaic Mycobacteriophage Genomes. Cell 2003, 113 (2), 171-182. Hatfull, G. F. Mycobacteriophages: Windows into Tuberculosis. PLoS Pathog. 2014, 10 (3), e1003953. Casjens, S. R.; Thuman-Commike, P. A. Evolution of Mosaically Related Tailed Bacteriophage Genomes Seen through the Lens of Phage P22 Virion Assembly. Virology 2011, 411 (2), 393-415.

[6] Grose, J. H.; Casjens, S. R. Understanding the Enormous Diversity of Bacteriophages: The Tailed Phages That Infect the Bacterial Family Enterobacteriaceae. Virology 2014, 468-470 (801), 421-443.

[7] Rakonjac, J.; Bennett, N. J.; Spagnuolo, J.; Gagic, D.; Russel, M. Filamentous Bacteriophage: Biology, Phage Display and Nanotechnology Applications. Curr. Issues Mol. Biol. 2011, 13 (2), 51-76.

[8] Ackermann, H. W.; DuBow, M. S. General Properties of Bacteriophages. In Viruses of Prokaryotes; CRC Press, 1987; p 202.

[9] Rakhuba, D. V.; Kolomiets, E. I.; Dey, E. S.; Novik, G. I. Bacteriophage Receptors, Mechanisms of Phage Adsorption and Penetration into Host Cell. Polish J. Microbiol. / Pol. Tow. Mikrobiol. $=$ Polish Soc. Microbiol. 2010, 59 (3), 145-155. 
[10] Osserman, E. F.; Canfield, R. E.; Beychok, S. Lysozyme; Osserman, E., Ed.; Academic Press Inc., 1974.

[11] Cenens, W.; Makumi, A.; Mebrhatu, M. T.; Lavigne, R.; Aertsen, A. Phage-Host Interactions during Pseudolysogeny: Lessons from the Pid/dgo Interaction. Bacteriophage 2013, (1), e25029.

[12] Roszniowski, B.; Latka, A.; Maciejewska, B.; Vandenheuvel, D.; Olszak, T.; Briers, Y.; Holt, G. S.; Valvano, M. A.; Lavigne, R.; Smith, D. L.; Drulis-Kawa, Z. The Temperate Burkholderia Phage AP3 of the Peduovirinae Shows Efficient Antimicrobial Activity against B. Cenocepacia of the IIIA Lineage. Appl. Microbiol. Biotechnol. 2017, 101 (3), 12031216.

[13] Weinbauer, M. G. Ecology of Prokaryotic Viruses. FEMS Microbiol. Rev. 2004, 28 (2), 127-181.

[14] Abedon, S. Phage Ecology. In The Bacteriophages 2nd edition; Calendar, R., Abedon, S. T., Eds.; Oxford University Press: New York, 2007; pp 37-39.

[15] Young, R. Phage Lysis: Do We Have the Hole Story Yet? Curr. Opin. Microbiol. 2013, 16 (6), 790-797.

[16] Young, R. Phage Lysis: Three Steps, Three Choices, One Outcome. J. Microbiol. 2014, 52 (3), 243-258.

[17] Erez, Z.; Steinberger-Levy, I.; Shamir, M.; Doron, S.; StokarAvihail, A.; Peleg, Y.; Melamed, S.; Leavitt, A.; Savidor, A.; Albeck, S.; Amitai, G.; Sorek, R. Communication between Viruses Guides Lysis-Lysogeny Decisions. Nature 2017, 1-18.

[18] Neidhardt, F. C.; Ingraham, J.; Low, K. Generalized Transduction. In Escherichia coli and Salmonella Typhimurium: cellular and Molecular Biology; American Society of Microbiology, 1996.

[19] Thierauf, A.; Perez, G.; Maloy, S. Generalized Transduction. In Bacteriophages: Methods and Protocols. Volume 1: Isolation, Characterization, and Interactions; Clokie, M. R. J., Kropinski, A., Eds.; Humana Press, 2009; pp 267-286.

[20] Wilhelm, S. W.; Suttle, C. a. Viruses and Nutrient Cycles in the Sea. Bioscience 1999, 49 (10), 781.

[21] Chaturongakul, S.; Ounjai, P. Phage-Host Interplay: Examples from Tailed Phages and Gram-Negative Bacterial Pathogens. Front. Microbiol. 2014, 5 (August), 442.

[22] Williams, H. T. P. Phage-Induced Diversification Improves Host Evolvability. BMC Evol. Biol. 2013, 13, 17.

[23] Clokie, M. R.; Millard, A. D.; Letarov, A. V; Heaphy, S. Phages in Nature. Bacteriophage 2011, 1 (1), 31-45.

[24] Fortier, L.-C.; Sekulovic, O. Importance of Prophages to Evolution and Virulence of Bacterial Pathogens. Virulence 2013, 4 (5), 354-365.

[25] Lebaron, P.; Servais, P.; Troussellier, M.; Courties, C.; VivesRego, J.; Muyzer, G.; Bernard, L.; Guindulain, T.; Schäfer, H.; Stackebrandt, E. Changes in Bacterial Community Structure in Seawater Mesocosms Differing in Their Nutrient Status. Aquat. Microb. Ecol. 1999, 19 (4), 255-267.

[26] Fuhrman, J. A. Marine Viruses and Their Biogeochemical and Ecological Effects. Nature 1999, 399 (6736), 541-548.

[27] Balcazar, J. L. Bacteriophages as Vehicles for Antibiotic Resistance Genes in the Environment. PLoS Pathog. 2014, 10 (7), e1004219.

[28] Colomer-Lluch, M.; Jofre, J.; Muniesa, M. Antibiotic Resistance Genes in the Bacteriophage DNA Fraction of Environmental Samples. PLoS One 2011, 6 (3), e17549.

[29] Wang, X.; Wood, T. K. Cryptic Prophages as Targets for Drug Development. Drug Resist. Updat. 2016, 27, 30-38.

[30] Feiner, R.; Argov, T.; Rabinovich, L.; Sigal, N.; Borovok, I.; Herskovits, A. A. A New Perspective on Lysogeny: Prophages as Active Regulatory Switches of Bacteria. Nat. Rev. Microbiol. 2015, 13 (10), 641-650.

[31] van Hannen, E. J.; Zwart, G.; van Agterveld, M. P.; Gons, H. J.; Ebert, J.; Laanbroek, H. J. Changes in Bacterial and Eukaryotic Community Structure after Mass Lysis of Filamentous Cyanobacteria Associated with Viruses. Appl. Environ Microbiol. 1999, 65 (2), 795-801.

[32] Bobay, L.-M.; Touchon, M.; Rocha, E. P. C. Pervasive Domestication of Defective Prophages by Bacteria. Proc. Natl. Acad. Sci. U. S. A. 2014, 111 (33), 12127-12132.

[33] Krupovic, M.; Prangishvili, D.; Hendrix, R. W.; Bamford, D. H. Genomics of Bacterial and Archaeal Viruses: Dynamics within the Prokaryotic Virosphere. Microbiol. Mol. Biol. Rev. 2011, 75 (4), 610-635.

[34] Casjens, S. Prophages and Bacterial Genomics: What Have We
Learned so Far? Mol. Microbiol. 2003, 49 (2), 277-300.

[35] Six, E. W.; Klug, C. A. Bacteriophage P4: A Satellite Virus Depending on a Helper such as Prophage P2. Virology 1973, 51 (2), 327-344

[36] Lang, A. S.; Zhaxybayeva, O.; Beatty, J. T. Gene Transfer Agents: Phage-like Elements of Genetic Exchange. Nat. Rev. Microbiol. 2012, 10 (7), 472-482.

[37] Hosseinidoust, Z.; van de Ven, T. G. M.; Tufenkji, N. Evolution of Pseudomonas Aeruginosa Virulence as a Result of Phage Predation. Appl. Environ. Microbiol. 2013, 79 (19), 6110-6116.

[38] Van Valen, L. A New Evolutionary Law. Evol. Theory 1973, 1 , $1-30$.

[39] Dawkins, R.; Krebs, J. R. Arms Races between and within Species. Proc. R. Soc. London. Ser. B, Biol. Sci. 1979, 205 (1161), 489-511.

[40] Stern, A.; Sorek, R. The Phage-Host Arms Race: Shaping the Evolution of Microbes. Bioessays 2011, 33 (1), 43-51.

[41] Samson, J. E.; Magadán, A. H.; Sabri, M.; Moineau, S. Revenge of the Phages: Defeating Bacterial Defences. Nat. Rev. Microbiol. 2013, 11 (10), 675-687.

[42] Lewis, K. Persister Cells. Annu. Rev. Microbiol. 2010, 64, 357 372.

[43] van der Oost, J.; Westra, E. R.; Jackson, R. N.; Wiedenheft, B. Unravelling the Structural and Mechanistic Basis of CRISPRCas Systems. Nat. Rev. Microbiol. 2014, 12 (7), 479-492.

[44] Twort, F. W. An Investigation on the Nature of the Ultramicroscopic Viruses. Lancet 1915, 186, 1241-1243.

[45] Ripp, S.; Miller, R. V. The Role of Pseudolysogeny in Bacteriophage-Host Interactions in a Natural Freshwater Environment. Microbiology 1997, 143 (6), 2065-2070.

[46] Łoś, M.; Węgrzyn, G. Pseudolysogeny. 2012, 82, 339-349.

[47] Koskella, B.; Brockhurst, M. A. Bacteria-Phage Coevolution as a Driver of Ecological and Evolutionary Processes in Microbial Communities. FEMS Microbiol. Rev. 2014, 38 (5), 916-931.

[48] Leiman, P. G.; Molineux, I. J. Evolution of a New Enzyme Activity from the Same Motif Fold. Molecular Microbiology. 2008, pp 287-290.

[49] Santos, S. B.; Fernandes, E.; Carvalho, C. M.; Sillankorva, S.; Krylov, V. N.; Pleteneva, E. a; Shaburova, O. V; Nicolau, a; Ferreira, E. C.; Azeredo, J. Selection and Characterization of a Multivalent Salmonella Phage and Its Production in a Nonpathogenic Escherichia Coli Strain. Appl. Environ. Microbiol. 2010, 76 (21), 7338-7342.

[50] Schwarzer, D.; Buettner, F. F. R.; Browning, C.; Nazarov, S.; Rabsch, W.; Bethe, A.; Oberbeck, A.; Bowman, V. D.; Stummeyer, K.; Mühlenhoff, M.; Leiman, P. G.; GerardySchahn, R. A Multivalent Adsorption Apparatus Explains the Broad Host Range of Phage phi92: A Comprehensive Genomic and Structural Analysis. J. Virol. 2012, 86 (19), 10384-10398.

[51] Otto, S. P. Two Steps Forward, One Step Back: The Pleiotropic Effects of Favoured Alleles. Proceedings. Biol. Sci. 2004, 271 (1540), 705-714.

[52] Gould, S. J.; Vrba, E. S. Exaptation-A Missing Term in the Science of Form. Paleobiology 1982, 8 (1), 4-15.

[53] Blount, Z. D.; Barrick, J. E.; Davidson, C. J.; Lenski, R. E. Genomic Analysis of a Key Innovation in an Experimental Escherichia Coli Population. Nature 2012, 489 (7417), 513518.

[54] Marinus, M. G.; Casadesus, J. Roles of DNA Adenine Methylation in Host-Pathogen Interactions: Mismatch Repair, Transcriptional Regulation, and More. In FEMS Microbiology Reviews; 2009; Vol. 33, pp 488-503.

[55] Srikhanta, Y. N.; Maguire, T. L.; Stacey, K. J.; Grimmond, S. M.; Jennings, M. P. The Phasevarion: A Genetic System Controlling Coordinated, Random Switching of Expression of Multiple Genes. Proc. Natl. Acad. Sci. U. S. A. 2005, 102 (15), 5547-5551.

[56] Seib, K. L.; Peak, I. R. A.; Jennings, M. P. Phase Variable Restriction-Modification Systems in Moraxella Catarrhalis. FEMS Immunol. Med. Microbiol. 2002, 32 (2), 159-165.

[57] Pedersen, K.; Christensen, S. K.; Gerdes, K. Rapid Induction and Reversal of a Bacteriostatic Condition by Controlled Expression of Toxins and Antitoxins. Mol. Microbiol. 2002, 45 (2), 501-510.

[58] Christensen, S. K.; Pedersen, K.; Hansen, F. G.; Gerdes, K. Toxin-antitoxin Loci as Stress-Response-Elements: ChpAK/MazF and ChpBK Cleave Translated RNAs and Are 
Counteracted by tmRNA. J. Mol. Biol. 2003, 332 (4), 809-819.

[59] León, M.; Bastías, R. Virulence Reduction in Bacteriophage Resistant Bacteria. Front. Microbiol. 2015, 6 (April), 343.

[60] van Houte, S.; Ekroth, A. K. E.; Broniewski, J. M.; Chabas, H.; Ashby, B.; Bondy-Denomy, J.; Gandon, S.; Boots, M.; Paterson, S.; Buckling, A.; Westra, E. R. The DiversityGenerating Benefits of a Prokaryotic Adaptive Immune System. Nature 2016, 532 (7599), 385-388.

[61] Cordero, O. X.; Polz, M. F. Explaining Microbial Genomic Diversity in Light of Evolutionary Ecology. Nat. Rev. Microbiol. 2014, 12 (4), 263-273.

[62] Dy, R. L.; Richter, C.; Salmond, G. P. C.; Fineran, P. C. Remarkable Mechanisms in Microbes to Resist Phage Infections. Annu. Rev. Virol. 2014, 1 (1), 307-331.

[63] Liu, M.; Deora, R.; Doulatov, S. R.; Gingery, M.; Eiserling, F. A.; Preston, A.; Maskell, D. J.; Simons, R. W.; Cotter, P. A.; Parkhill, J.; Miller, J. F. Reverse Transcriptase-Mediated Tropism Switching in Bordetella Bacteriophage. Science 2002 295 (5562), 2091-2094.

[64] Doulatov, S.; Hodes, A.; Dai, L.; Mandhana, N.; Liu, M.; Deora, R.; Simons, R. W.; Zimmerly, S.; Miller, J. F. Tropism Switching in Bordetella Bacteriophage Defines a Family of Diversity-Generating Retroelements. Nature 2004, 431 (7007), 476-481.

[65] Pedruzzi, I.; Rosenbusch, J. P.; Locher, K. P. Inactivation in Vitro of the Escherichia Coli Outer Membrane Protein FhuA by a Phage T5-Encoded Lipoprotein. FEMS Microbiol. Lett. 1998, 168 (1), 119-125.

[66] Foster, T. J. Immune Evasion by Staphylococci. Nat. Rev. Microbiol. 2005, 3 (12), 948-958.

[67] Levin, B. R.; Bull, J. J. Population and Evolutionary Dynamics of Phage Therapy. Nat. Rev. Microbiol. 2004, 2 (2), 166-173.

[68] Scott, A. E.; Timms, A. R.; Connerton, P. L.; Loc Carrillo, C.; Adzfa Radzum, K.; Connerton, I. F. Genome Dynamics of Campylobacter Jejuni in Response to Bacteriophage Predation. PLoS Pathog. 2007, 3 (8), e119.

[69] Riede, I.; Eschbach, M. L. Evidence That TraT Interacts with OmpA of Escherichia Coli. FEBS Lett. 1986, 205 (2), 241-245.

[70] German, G. J.; Misra, R. The TolC Protein of Escherichia Coli Serves as a Cell-Surface Receptor for the Newly Characterized TLS Bacteriophage. J. Mol. Biol. 2001, 308 (4), 579-585.

[71] Labrie, S. J.; Samson, J. E.; Moineau, S. Bacteriophage Resistance Mechanisms. Nat. Rev. Microbiol. 2010, 8 (5), 317327.

[72] Scholl, D.; Adhya, S.; Merril, C. Escherichia Coli K1's Capsule Is a Barrier to Bacteriophage T7. Appl. Environ. Microbiol. 2005, 71 (8), 4872-4874.

[73] van der Ley, P.; de Graaff, P.; Tommassen, J. Shielding of Escherichia Coli Outer Membrane Proteins as Receptors for Bacteriophages and Colicins by O-Antigenic Chains of Lipopolysaccharide. J. Bacteriol. 1986, 168 (1), 449-451.

[74] Kim, E.-J.; Lee, H.; Lee, J.-H.; Ryu, S.; Park, J.-H. Morphological Features and Lipopolysaccharide Attachment of Coliphages Specific to Escherichia Coli O157:H7 and to a Broad Range of E. Coli Hosts. Appl. Biol. Chem. 2016, 59 (1), 109-116.

[75] Turner, P. E.; Duffy, S. Evolutionary Ecology of Multiple Phage Adsorption and Infection. In Bacteriophage Ecology; Abedon, S. T., Ed.; Cambridge University Press: Cambridge, 2008; pp 195-216.

[76] Hofer, B.; Ruge, M.; Dreiseikelmann, B. The Superinfection Exclusion Gene (sieA) of Bacteriophage P22: Identification and Overexpression of the Gene and Localization of the Gene Product. J. Bacteriol. 1995, 177 (11), 3080-3086.

[77] Lu, M. J.; Stierhof, Y. D.; Henning, U. Location and Unusual Membrane Topology of the Immunity Protein of the Escherichia Coli Phage T4. J. Virol. 1993, 67 (8), 4905-4913. Tock, M. R.; Dryden, D. T. The Biology of Restriction and Anti-Restriction. Curr. Opin. Microbiol. 2005, 8 (4), 466-472.

[79] Krüger, D. H.; Bickle, T. A. Bacteriophage Survival: Multiple Mechanisms for Avoiding the Deoxyribonucleic Acid Restriction Systems of Their Hosts. Microbiol. Rev. 1983, 47 (3), 345-360.

[80] Pingoud, A. M. Restriction Endonucleases; Pingoud, A. M., Ed.; Springer Verlag: Berlin, 2004.

[81] Makarova, K. S.; Haft, D. H.; Barrangou, R.; Brouns, S. J. J. Charpentier, E.; Horvath, P.; Moineau, S.; Mojica, F. J. M.; Wolf, Y. I.; Yakunin, A. F.; van der Oost, J.; Koonin, E. V.
Evolution and Classification of the CRISPR-Cas Systems. Nat. Rev. Microbiol. 2011, 9, 467-477.

[82] Dupuis, M.-̇̀; Villion, M.; Magadán, A. H.; Moineau, S CRISPR-Cas and Restriction-Modification Systems Are Compatible and Increase Phage Resistance. Nat. Commun. 2013, 4 (May), 2087.

[83] Yosef, I.; Goren, M. G.; Qimron, U. Proteins and DNA Elements Essential for the CRISPR Adaptation Process in Escherichia Coli. Nucleic Acids Res. 2012, 40 (12), 5569-5576.

[84] Brouns, S. J. J.; Jore, M. M.; Lundgren, M.; Westra, E. R.; Slijkhuis, R. J. H.; Snijders, A. P. L.; Dickman, M. J.; Makarova, K. S.; Koonin, E. V.; van der Oost, J. Small CRISPR RNAs Guide Antiviral Defense in Prokaryotes. Science (80-. ). 2008, 321 (5891), 960-964.

[85] Sorek, R.; Kunin, V.; Hugenholtz, P. CRISPR--a Widespread System That Provides Acquired Resistance against Phages in Bacteria and Archaea. Nat. Rev. Microbiol. 2008, 6 (3), 181186.

[86] Shub, D. A. Bacterial Viruses. Bacterial Altruism? Curr. Biol. 1994, 4 (6), 555-556.

[87] Chopin, M.-C.; Chopin, A.; Bidnenko, E. Phage Abortive Infection in Lactococci: Variations on a Theme. Curr. Opin. Microbiol. 2005, 8 (4), 473-479.

[88] Cheng, X.; Wang, W.; Molineux, I. J. F Exclusion of Bacteriophage T7 Occurs at the Cell Membrane. Virology 2004, 326 (2), 340-352.

[89] Brussaard, C. P. D.; Wilhelm, S. W.; Thingstad, F.; Weinbauer, M. G.; Bratbak, G.; Heldal, M.; Kimmance, S. a; Middelboe, M.; Nagasaki, K.; Paul, J. H.; Schroeder, D. C.; Suttle, C. a; Vaqué, D.; Wommack, K. E. Global-Scale Processes with a Nanoscale Drive: The Role of Marine Viruses. ISME J. 2008, 2 (6), 575-578

[90] Azam, F. Oceanography: Microbial Control of Oceanic Carbon Flux: The Plot Thickens. Science (80-. ). 1998, 280 (5364), 694-696.

[91] Shelford, E.; Middelboe, M.; Møller, E.; Suttle, C. VirusDriven Nitrogen Cycling Enhances Phytoplankton Growth. Aquat. Microb. Ecol. 2012, 66 (1), 41-46.

[92] Caron, D. A. Inorganic Nutrients, Bacteria, and the Microbial Loop. Microb. Ecol. 1994, 28 (2), 295-298.

[93] Rosenberg, E.; Bittan-Banin, G.; Sharon, G.; Shon, A.; Hershko, G.; Levy, I.; Ron, E. Z. The Phage-Driven Microbial Loop in Petroleum Bioremediation. Microb. Biotechnol. 2010 3 (4), 467-472.

[94] Ventura, M.; Sozzi, T.; Turroni, F.; Matteuzzi, D.; van Sinderen, D. The Impact of Bacteriophages on Probiotic Bacteria and Gut Microbiota Diversity. Genes Nutr. 2011, 6 (3), 205-207.

[95] Obeng, N.; Pratama, A. A.; Elsas, J. D. van. The Significance of Mutualistic Phages for Bacterial Ecology and Evolution. Trends Microbiol. 2016, 24 (6), 440-449.

[96] Stamp, N. Out of the Quagmire of Lant Defense Hypotheses. Q. Rev. Biol. 2003, 78 (1), 23-55.

[97] Thingstad, T. F. Elements of a Theory for the Mechanisms Controlling Abundance, Diversity, and Biogeochemical Role of Lytic Bacterial Viruses in Aquatic Systems. Limnol. Oceanogr. 2000, 45 (6), 1320-1328.

[98] Proctor, L. . Marine Virus Ecology. In Molecular Approaches to the Study of the Ocean; Cooksey, K. E., Ed.; Springer Netherlands: Dordrecht, 1998; pp 113-130.

[99] Edlin, G.; Lin, L.; Bitner, R. Reproductive Fitness of P1, P2 and Mu Lysogens of Escherichia Coli. J. Virol. 1977, 21 (2), 560-564.

[100] Lin, L.; Bitner, R.; Edlin, G. Increased Reproductive Fitness of Escherichia Coli Lambda Lysogens. J. Virol. 1977, 21 (2), 554-559.

[101] Brown, S. P.; Le Chat, L.; De Paepe, M.; Taddei, F. Ecology of Microbial Invasions: Amplification Allows Virus Carriers to Invade More Rapidly When Rare. Curr. Biol. 2006, 16 (20), 2048-2052.

[102] Gama, J. A.; Reis, A. M.; Domingues, I.; Mendes-Soares, H.; Matos, A. M.; Dionisio, F. Temperate Bacterial Viruses as Double-Edged Swords in Bacterial Warfare. PLoS One 2013, 8 (3), e59043.

[103] Joo, J.; Gunny, M.; Cases, M.; Hudson, P.; Albert, R.; Harvill, E. Bacteriophage-Mediated Competition in Bordetella Bacteria. Proc. Biol. Sci. 2006, 273 (1595), 1843-1848.

[104] Lopez Pascua, L.; Gandon, S.; Buckling, A. Abiotic 
Heterogeneity Drives Parasite Local Adaptation in Coevolving Bacteria and Phages. J. Evol. Biol. 2012, 25 (1), 187-195.

[105] Gorter, F. a; Scanlan, P. D.; Buckling, A. Adaptation to Abiotic Conditions Drives Local Adaptation in Bacteria and Viruses Coevolving in Heterogeneous Environments. Biol. Lett. 2016, 12 (2), 20150879

[106] Friman, V.-P.; Hiltunen, T.; Jalasvuori, M.; Lindstedt, C.; Laanto, E.; Örmälä, A.-M.; Laakso, J.; Mappes, J.; Bamford, J. K. H. High Temperature and Bacteriophages Can Indirectly Select for Bacterial Pathogenicity in Environmental Reservoirs. PLoS One 2011, 6 (3), e17651.

[107] Maslov, S.; Sneppen, K. Well-Temperate Phage: Optimal BetHedging against Local Environmental Collapses. Sci. Rep. 2015, 5, 10523 .

[108] Hall-Stoodley, L.; Costerton, J. W.; Stoodley, P. Bacterial Biofilms: From the Natural Environment to Infectious Diseases. Nat. Rev. Microbiol. 2004, 2 (2), 95-108.

[109] McDougald, D.; Rice, S. a.; Barraud, N.; Steinberg, P. D.; Kjelleberg, S. Should We Stay or Should We Go: Mechanisms and Ecological Consequences for Biofilm Dispersal. Nat. Rev. Microbiol. 2012, 10 (1), 39-50.

[110] Hui, J. G. K.; Mai-Prochnow, A.; Kjelleberg, S.; McDougald, D.; Rice, S. A. Environmental Cues and Genes Involved in Establishment of the Superinfective Pf4 Phage of Pseudomonas Aeruginosa. Front. Microbiol. 2014, 5 (DEC), 654.

[111] Abedon, S. T. Ecology of Anti-Biofilm Agents I: Antibiotics versus Bacteriophages. Pharmaceuticals (Basel). 2015, 8 (3), $525-558$

[112] Abedon, S. T. Ecology of Anti-Biofilm Agents II: Bacteriophage Exploitation and Biocontrol of Biofilm Bacteria. Pharmaceuticals (Basel). 2015, 8 (3), 559-589.

[113] Odum, E. . Fundamentals of Ecology; W.B. Saunders Co. Philadelphia, PA, 1953

[114] Rodriguez-Valera, F.; Martin-Cuadrado, A.-B.; RodriguezBrito, B.; Pasić, L.; Thingstad, T. F.; Rohwer, F.; Mira, A Explaining Microbial Population Genomics through Phage Predation. Nat. Rev. Microbiol. 2009, 7 (11), 828-836.

[115] Bohannan, B. J. M.; Lenski, R. E. Linking Genetic Change to Community Evolution: Insights from Studies of Bacteria and Bacteriophage. Ecol. Lett. 2000, 3 (4), 362-377.

[116] Haerter, J. O.; Mitarai, N.; Sneppen, K. Phage and Bacteria Support Mutual Diversity in a Narrowing Staircase of Coexistence. ISME J. 2014, 8 (11), 2317-2326.

[117] Thingstad, T. F.; Lignell, R. Theoretical Models for the Control of Bacterial Growth Rate, Abundance, Diversity and Carbon Demand. Aquat. Microb. Ecol. 1997, 13, 19-27.

[118] Bächi, B.; Reiser, J.; Pirrotta, V. Methylation and Cleavage Sequences of the EcoP1 Restriction-Modification Enzyme. $J$. Mol. Biol. 1979, 128 (2), 143-163.

[119] Makarova, K. S.; Wolf, Y. I.; Koonin, E. V. Comparative Genomics of Defense Systems in Archaea and Bacteria. Nucleic Acids Res. 2013, 41 (8), 4360-4377.

[120] Knowles, B.; Silveira, C. B.; Bailey, B. A.; Barott, K.; Cantu, V. A.; Cobián-Güemes, A. G.; Coutinho, F. H.; Dinsdale, E. A.; Felts, B.; Furby, K. A.; George, E. E.; Green, K. T.;

Gregoracci, G. B.; Haas, A. F.; Haggerty, J. M.; Hester, E. R.; Hisakawa, N.; Kelly, L. W.; Lim, Y. W.; Little, M.; Luque, A.; McDole-Somera, T.; McNair, K.; de Oliveira, L. S.; Quistad, S. D.; Robinett, N. L.; Sala, E.; Salamon, P.; Sanchez, S. E.; Sandin, S.; Silva, G. G. Z.; Smith, J.; Sullivan, C.; Thompson, C.; Vermeij, M. J. A.; Youle, M.; Young, C.; Zgliczynski, B.; Brainard, R.; Edwards, R. A.; Nulton, J.; Thompson, F.; Rohwer, F. Lytic to Temperate Switching of Viral Communities. Nature 2016, 531 (7595), 466-470. 